\title{
Sustainability of Artisanal Fishers Livelihoods in the Jebba Lake Basin, Nigeria Http://dx.doi.org/10.4314/jae.v20i1.6
}

Nwabeze, G. 0 .

Extension Programme, National Institute for Freshwater Fisheries Research (NIFFR), P.M.B. 6006, New Bussa, Niger State.

Email: onyegodfrey@yahoo.com

Phone: 08052923218

\section{Abstract}

The study examined sustainability of artisanal fishers' livelihoods in the Jebba Lake Basin, Nigeria. Multi-stage sampling technique was used to select 402 respondents for the study. Semi-structured interview schedule was employed for data collection. Data were analysed using percentages, mean, standard deviation, sustainability index and Herfindel livelihood index. Most respondents (88.6\%) were engaged in non-fishing livelihood activities especially crop farming and livestock rearing. The study found that respondents' access to fishing ground ( $\bar{x}$ $=4.66, S D=0.61)$ and agricultural land $(\bar{x}=3.61, S D=0.89)$ was sustainable. Social assets among the respondents indicated good entry point for policy advocacy and intervention. The sustainability index (0.57) of the respondents indicated that the livelihoods of the respondents are unsustainable. The Herfindel livelihood diversification index $\left(L D I_{H}=0.43\right)$ revealed a high level of diversification among the respondents. The study concludes that livelihoods in the Jebba Lake Basin are unsustainable to the fishers' household. It is recommended that government should enhance fisheries activities by making available adequate mitigating strategies for increased and sustainable fish yield.

Keywords: Sustainability of fishing livelihood activities, fishing livelihood activities in Nigeria

\section{Introduction}

Artisanal fisheries worldwide account for significant source of food for sustaining human well-being over the years. Fish is of great importance as a direct source of protein for millions of people constituting about $41 \%$ of the total animal protein intake by the average Nigerian (FAO, 2002). In Nigeria, fisheries do not merely supply an essential alternative source of animal protein but is also critical to the economy 
Creative commons User License: CC BY-NC-ND

Abstracted by: EBSCOhost, Electronic Journals Service (EJS),

Google Scholar, Directory of Open Access Journals (DOAJ),

Journal Seek, Scientific Commons,

Food and Agricultural Organization (FAO), andCABI
Journal of Agricultural Extension

Vol. 20 (1) June, 2016

ISSN(e): 24086851; ISSN(Print); 1119944X

http://journal.aesonnigeria.org

http://www.ajol.info/index.php/iae

Email: editorinchief@aesonnigeria.org

contributing $5 \%$ of agricultural Gross Domestic Product (FAO, 2007). Inland artisanal fisheries are mainly concerned with small scale fishers characterized by the use of low technology fishing gear over a restricted range, are basically important to the development of the nation's economy, providing sources of protein and livelihoods of riparian communities (FAO, 2004). Inland fisheries accounted for $85 \%$ of domestic fish production between 1991 and 2003 with total annual fish production of 615,507 in 2007 (FDF, 2008). Regardless of this contribution of inland fisheries and its potential in national economic development, its sustainability is being endangered (Mutume, 2002).

Furthermore, inspite of the vast potential of abundant fisheries resources, Nigeria remains a very large importer of fish and fishery products with a total consumption of about 1.2 million tons out of which about 650,000 tons is imported annually to satisfy the dietary requisite of its citizens (FAO, 2008). Reasons for this has been ascribed to the survival nature of fishers, the seclusion of fishing communities and the complexity in accessing and use of outdated fishing gears and craft (Ohen, Agom and Okon, 2009) including use of unsustainable fisheries management practices adopted by the fishers (Nwabeze and Erie, 2013). Local fish production (in metric tones) for a period of 12 years (1995 to 2007) has been almost constant (FDF, 2008), indicating unsustainable fisheries resources.

The need to undo dwindling trend in capture fisheries resources informed government effort in formulating and implementing fisheries co-management. This requires the involvement of all stakeholders including fishers in the management of fisheries resources. In spite of this effort the fishery sector is yet to improve its yield significantly. Regrettably, annual national fish production is about 700,000 metric tons out of a huge demand of 1.7million metric tons in year 2010 (FDF, 2010). Fisheries are not only about managing the fish but are also intended to generate economic benefits for continued sustenance of fishers whose livelihoods depend on it. The means of survival of fishers in the face of declining fishery resources is significant for 
effective fishery management. It is against this backdrop that this study attempt to carry out sustainability assessment of artisanal fishers' livelihoods in Jebba Lake Basin, Nigeria. The specific objectives of this study were to;
i. identify livelihood activities of the respondents;
ii. examine the asset base of the respondents; and
iii. carry out sustainability assessment of fishery production

\section{Methodology}

The study was carried out in fishing communities in the Jebba Lake Basin, Nigeria. Jebba Lake is situated between Latitude 9' 10' and 9० 55' North and Longitude $4^{\circ} 30^{\prime}$ and $5^{\circ} 00^{\prime}$ East and was formed in August 1983 as an impoundment of River Niger (Olufemi, 2008). The lake is unique as the first and the only man-made lake in Nigeria that has a direct inflow from another man-made lake located upstream to it. It is bounded by Niger State on the east and Kwara State on the west.

Multi-stage sampling technique was used for the study. The first stage was the stratification of communities within the lake basin into Local Government Areas (LGAs). The communities within the lake basin fall into three LGAs in Niger state (Borgu, Magama and Mokwa) and 1 in Kwara state (Moro). The second stage was the stratification of the communities around the Lake into three strata to have a representation of fishing communities within the Northern, Southern and Central part of the lake across the four LGAs of the states. Identification of active fishing communities around the Lake Basin and purposive selection of $30 \%$ of total number of identified fishing villages by stratum formed the third stage. Thus; stratum one included the following communities: Fakun, Bakoshi, Faransawa, Sabo Leaba and New Awuru; stratum two comprised Sabo Niger, Tungan Lanti, Kwaifawa, Rimaye, Tsofo Gbajibo and Tungan Maje while stratum three comprised Tungan Alhaji Audu, Saminaka, Tugan Dukia, Tungan Kwakwari, Ngagi 1, Gungu Zaki and Tungan Garba Bichi. The fourth step was the purposive selection of 18 percent of fishers in each of the selected fishing communities from the three strata. Thus, 134 fishers were 
Creative commons User License: CC BY-NC-ND

Abstracted by: EBSCOhost, Electronic Journals Service (EJS),

Google Scholar, Directory of Open Access Journals (DOAJ),

Journal Seek, Scientific Commons,

Food and Agricultural Organization (FAO), andCABI
Journal of Agricultural Extension

Vol. 20 (1) June, 2016

ISSN(e): 24086851; ISSN(Print); 1119944X

http://journal.aesonnigeria.org

http://www.ajol.info/index.php/iae

Email: editorinchief@aesonnigeria.org

sampled from stratum one, 130 from stratum two and 138 from stratum three, making a total of 402 fishers sampled for the study Semi-structured interview schedule was employed for data collection. Data were analysed using descriptive statistics (percentages, mean, and standard deviation) and inferential statistics (sustainability index and Herfindel livelihood index).

\section{Measurement of variables}

\section{Sustainability index}

This is the ability of the household to cope and recover from stresses and shocks related to vulnerability. It also deals with the ability to maintain its capacity and assets base. This was achieved by rating respondents on four-point Likert scale of strongly agree $=4$, agree $=3$, disagree $=2$, and strongly disagree $=1$, based on their responses to the following statements;

i. Fishing community's location is not too remote for any improvement in livelihood

portfolios

ii. Communities are accessible despite deplorable road network

iii. Planning to leave fishing business

iv. Have access to credit facilities to support other livelihood activities

v. Capable of maintaining and sustaining assets base

vi. Relocate to better and more favourable area

vii. Market situation is favourable to livelihood activities

viii. Number of people in the area is not a problem to livelihood activities

ix. Changes in flood / rain cycle is not a problem

x. Conflict is not a problem in the area

In calculating the sustainability index, the mid-point values of the scale $(1+2+3+4)$ were summed up to get 10 . The sum was further divided by 4 to obtain 2.5 which is the weighted mean. The mean for each sustainability source was obtained by multiplying the point scale by the number of respondents in each point scale. Any 
Creative commons User License: CC BY-NC-ND

Abstracted by: EBSCOhost, Electronic Journals Service (EJS),

Google Scholar, Directory of Open Access Journals (DOAJ),

Journal Seek, Scientific Commons,

Food and Agricultural Organization (FAO), andCABI
Journal of Agricultural Extension

Vol. 20 (1) June, 2016

ISSN(e): 24086851; ISSN(Print); 1119944X

http://journal.aesonnigeria.org

http://www.ajol.info/index.php/iae

Email: editorinchief@aesonnigeria.org

sustainability source with a mean score equal or above the cut off mean of 2.5 was regarded as an important (agreed) source of sustainability and any mean score of lower than 2.5 as not an important (not agreed) source of sustainability. To get the sustainability index, respondents scores on the 10 items were summed up and divided by the expected total score on the 10 items (which in this case is 40 that is 10 multiply by 4 , the highest scale representing strongly agree).

\section{Capital assets enumeration}

Capital assets (natural assets, human assets, physical assets, social assets and financial assets) enumeration was done by rating respondents on the quality of livelihood assets using Likert scale of Excellent (abundant assets base) - coded 5, very good (progressive) - 4, good (sustainable assets base) - 3, poor (constrained assets base) - 2 and very poor (unsustainable assets base) - 1. Based on their responses, any score below the mean (3.00) indicated weak and restricted livelihood assets status while a score of 3.00 and above indicate otherwise.

\section{Computation of livelihood diversification index}

This was used to capture the various levels of livelihood activities engaged by the fishers. Hence, the following indexes were computed:

1. The livelihood diversification index (LDI), using Herfindel index was used to measure the degree of livelihood diversification.

2. Geometric index (Gl) was fitted to capture the vulnerability of fishing income to other sources of income as well as total income.

Herfindel index given as $L^{\prime} I_{H}=\frac{1}{N} \sum_{i=1}^{q} \mathrm{Ni}^{2}$

Where $\frac{1}{N} \sum_{i=1}^{q} \frac{\mathrm{Bi}}{\mathrm{Ai}}$

Where $\mathrm{LDI}_{\mathrm{H}}=$ Livelihood diversification index

$\mathrm{Ni}=$ Proportion of fishing income

$\mathrm{Bi}=$ Gross income from fishing

$A i=$ Total income from all the activities 
If $0<\mathrm{LDI}<1$. The lower LDI falls below 1 , the higher the degree of diversification, and vice versa.

The Geometric Index (Gl) is meant to capture the weighted means (i.e. its vulnerability) of each activity income on total income of all activities in sample areas. Similar approach has been used by Dercon (2001), Qizibashi (2001) and Apata, Akinlua and Igbalajobi (2009).

$\mathrm{Gl}=\frac{1}{N} \sum_{i=1}^{q} \mathrm{Wi} \mathrm{i}=1,2, \ldots, \mathrm{n} \ldots \ldots \ldots \ldots \ldots \ldots \ldots \ldots \ldots \ldots \ldots \ldots \ldots \ldots \ldots$

$\mathrm{GI}=$ Geometric Index

$\mathrm{n}=$ number of occupations in a combination

$\mathrm{Wi}=$ particular weight attached to each class of occupation (proxied as income proportion). The higher the index the higher is its vulnerability that is, the likelihood to help minimize risk and boost income.

\section{Results and Discussion}

\section{Livelihoods of respondents}

Table 1 reveals that most (88.6\%) respondents engaged in farming. From the opinion sought on the relevance of farming to livelihoods and whether fishers would leave fishing for farming, it was found that fishers would never leave fishing even if they make very high income from farming and other sources. About $86.3 \%$ of the respondents were involved in livestock rearing as the second most important livelihood. These were mainly extensive poultry (local chicken, ducks and guinea fowl), small ruminant farming (sheep and goat) and insignificant number of cattle rearing. Other livelihoods of the respondents were petty trading (21.9\%), skilled trade (3.2\%) and fish farming (5.2\%). The finding corroborates that of Oyesola and Oladeji (2008) that rural dwellers are involved in more than one income generating activity in order to adjust and cope with poverty.

The variation in livelihoods is because fishers differ in access to livelihood assets (Table 2) productive resources and opportunities for securing livelihoods and therefore engaged in livelihood that they have advantage over the others. Fishers in 
Creative commons User License: CC BY-NC-ND

Abstracted by: EBSCOhost, Electronic Journals Service (EJS),

Google Scholar, Directory of Open Access Journals (DOAJ),

Journal Seek, Scientific Commons,

Food and Agricultural Organization (FAO), andCABI
Journal of Agricultural Extension

Vol. 20 (1) June, 2016

ISSN(e): 24086851; ISSN(Print); 1119944X

http://journal.aesonnigeria.org

http://www.ajol.info/index.php/iae

Email: editorinchief@aesonnigeria.org

the area also confirmed that fishing is no longer lucrative in recent time and they derive much of their subsistence from farming. The findings agreed with the assertions of Apata and Rahji (2012) that artisanal fisher folks are more involved in farming than fishing as a livelihood.

Table 1: Non-fishing livelihoods sources of respondents

\begin{tabular}{ll}
\hline Livelihoods & Percentage* $\mathbf{~} \mathbf{n}=\mathbf{4 0 2})^{\text {Farming }}$ \\
Livestock rearing (poultry, medium and large) & 88.6 \\
Petty trading & 86.3 \\
Skilled trade & 21.9 \\
Transportation & 3.2 \\
Fish farming & 2.7 \\
\hline
\end{tabular}

${ }^{*}$ Multiple responses

\section{Livelihoods Asset-base of Respondents}

Assets are stocks of direct and indirect productive factors that produce a stream of cash and endowments. The livelihood asset-base of the respondents considered for the study include; natural assets, human assets, physical assets, social assets and financial assets as shown in Table 2. The distribution revealed that majority of the respondents fell between poor (constrained) and good (sustainable) assets from all the categories enumerated. The result revealed that respondents' access to fishing ground $(\bar{x}=4.66, \quad \mathrm{SD}=0.61))$ and agricultural land $(\bar{x}=3.61, \quad \mathrm{SD}=0.89)$ was sustainable. This is significant in promoting active fishing and farming livelihoods in the study area. Further analyses show that respondents operate below sustainable educational status ( $\bar{x}=1.71, \mathrm{SD}=0.61$ ). This is significant in the kind of non-fishing livelihoods that fishing households could be engaged in. Respondents show low level of skill and capacity in other livelihoods ( $\bar{x}=2.28, \mathrm{SD}=0.68$ ). This is a major entry requirement for non-fishing livelihoods. 
Creative commons User License: CC BY-NC-ND

Abstracted by: EBSCOhost, Electronic Journals Service (EJS),

Google Scholar, Directory of Open Access Journals (DOAJ),

Journal Seek, Scientific Commons,

Food and Agricultural Organization (FAO), andCABI
Journal of Agricultural Extension

Vol. 20 (1) June, 2016

ISSN(e): 24086851; ISSN(Print); 1119944X

http://journal.aesonnigeria.org

http://www.ajol.info/index.php/iae

Email: editorinchief@aesonnigeria.org

Infrastructure/social amenities ( $\bar{x}=1.47, \mathrm{SD}=0.54)$ were abhorrently inadequate and absent in most of the communities. This implies that they are disconnected and have no access to infrastructure/social amenities that could improve livelihood opportunities. This explains the total absence of the three tiers of government in most of the fishing communities. The community members travel for a distance of not less than $10 \mathrm{~km}$ to access health care facilities. There were no schools in over $90.0 \%$ of the fishing communities' in spite of government effort on achievement of basic primary education for Nigeria.Most of the respondents lamented on their state of abandonment with respect to school, hospital, road network and electricity.

Socially, most $(80.0 \%)$ of the assets enumerated were near sustainable level. This indicates that there is strong social cohesion in fishing communities and is known to rely heavily on social network for livelihood improvement. This implies that social network allows the development of organized structures for non subsistence activities, adequate to compensate for restriction in livelihood assets and provide diverse employment and income generation. In respect of financial assets, about $60.0 \%$ of the assets enumerated were unsustainable. This remains a fundamental problem among fishing households that wish to diversify from fishing to non-fishing livelihoods. 
Creative commons User License: CC BY-NC-ND

Abstracted by: EBSCOhost, Electronic Journals Service (EJS),

Google Scholar, Directory of Open Access Journals (DOAJ),

Journal Seek, Scientific Commons,

Food and Agricultural Organization (FAO), andCABI
Journal of Agricultural Extension

Vol. 20 (1) June, 2016

ISSN(e): 24086851; ISSN(Print); $1119944 X$

http://journal.aesonnigeria.org

http://www.ajol.info/index.php/jae

Email: editorinchief@aesonnigeria.org

\section{Table 2: Livelihoods asset base of respondents}

\begin{tabular}{|c|c|c|}
\hline Livelihoods Assets & Mean & Std. Deviation \\
\hline \multicolumn{3}{|l|}{ Natural assets } \\
\hline Access to water body (fishing ground) & $4.66^{*}$ & 0.61 \\
\hline Fisheries resources & 2.02 & 0.47 \\
\hline Access to agricultural land & $3.61^{*}$ & 0.89 \\
\hline Forest resources & 2.48 & 0.84 \\
\hline Access to mineral deposit & 1.69 & 0.75 \\
\hline Seasonal benefit had from the climate & 2.25 & 0.66 \\
\hline \multicolumn{3}{|l|}{ Human assets } \\
\hline Health status & 2.43 & 0.64 \\
\hline Family labour (skilled) & 2.64 & 0.83 \\
\hline Educational status (formal) & 1.71 & 0.61 \\
\hline Skill / capacity in other livelihood & 2.28 & 0.68 \\
\hline \multicolumn{3}{|l|}{ Physical assets } \\
\hline Ownership of building / housing & 2.35 & 0.72 \\
\hline Possession of fishing gears and craft & 1.92 & 0.57 \\
\hline Presence of good infrastructure / social amenities & 1.47 & 0.54 \\
\hline Possession of modern household appliances & 2.07 & 0.43 \\
\hline \multicolumn{3}{|l|}{ Social assets } \\
\hline Social network & 2.15 & 0.66 \\
\hline Community / group responsibility & 2.50 & 0.78 \\
\hline Cosmopoliteness & 1.96 & 0.77 \\
\hline Access to community leaderships & 2.61 & 0.87 \\
\hline Recognition for gender roles and responsibility & 2.91 & 0.65 \\
\hline \multicolumn{3}{|l|}{ Financial assets } \\
\hline Remittances & 2.19 & 1.50 \\
\hline Access to credit facilities & 1.68 & 1.50 \\
\hline Investment worth & 1.95 & 1.50 \\
\hline Cash elsewhere (lend) & 2.36 & 1.54 \\
\hline Cash at hand & 1.22 & 0.47 \\
\hline
\end{tabular}

${ }^{*}$ Good $($ mean $\geq 3.00)$ 


\section{Sustainability of Fishery Production}

Table 3 shows the mean values of sustainability assessment of respondents in fishery production. Respondents agreed that location of fishing communities is not too remote for any improvement in livelihoods portfolios ( $\bar{x}=2.93, \mathrm{SD}=0.76)$. This is an indication that respondents are optimistic that someday they will be part of rural transformation. The result further revealed that migration to better and more favourable fishing location $(\bar{x}=2.64, \mathrm{SD}=0.70)$ encouraged fishers in fishery production. Respondents' capabilities in maintaining and sustaining fishery resource base $(\bar{x}=2.60, \mathrm{SD}=0.52)$ and effective resolution of conflict $(\bar{x}=2.60, \mathrm{SD}=0.78)$ arising from the use of fishery resource are evidence of fishery co-management system in the area. In the face of fast depleting capture fishery resource, respondents agreed to remain in fishing business $(\bar{x}=2.50, S D=0.76)$ implying that fishing livelihoods account significantly for their household daily disposable income. Daily return from sales of fish caught contributes in meeting the day to day needs of fishers' households. Low responses on accessibility of fishing communities ( $\bar{x}=1.83$, $\mathrm{SD}=0.81)$ and access to credit facilities to support other livelihoods $(\bar{x}=1.33$, $\mathrm{SD}=0.62$ ) depict weak physical and financial assets that sustain fishery production. The finding support DFID/FAO (2004) assertion that fishing communities lack adequate assets to support and improve livelihoods. Respondents felt that increase in fishers' number will likely lead to increase pressure on fishery resource $(\bar{x}=2.0$, $\mathrm{SD}=0.78$ ). Respondents disagreed that their market situation is favourable to enhanced fishing livelihood ( $\bar{x}=2.39, \mathrm{SD}=0.76)$. Also, unfavourable market situation to fishing livelihood implies exploitation of fish mongers in the chain of distribution. Most of the fishers received loans from mongers for procurement of fishing input. These loans were remitted by fishers with fish caught and the bargaining power lies in the hand of the mongers. 


\section{Table 3: Sustainability assessment of fishery production}

\begin{tabular}{lcc}
\hline Sustainability assessment & Mean & Std. Deviation \\
\hline $\begin{array}{l}\text { Fishing communities location is not remote for any } \\
\text { improvement in livelihood portfolios }\end{array}$ & $2.93^{*}$ & 0.763 \\
Migrate to better and more favourable fishing location & $2.64^{*}$ & 0.696 \\
Capable of maintaining and sustaining fishery resource & $2.60^{*}$ & 0.524 \\
base & $2.60^{*}$ & 0.778 \\
Conflict is not a problem in the area & $2.50^{*}$ & 0.758 \\
Planning to remain in fishing business & 2.39 & 0.763 \\
Market situation is favourable to fishing livelihood & 2.10 & 0.876 \\
Changes in flood / rain cycle is not a problem & 2.00 & 0.777 \\
Increased number of fishers in the area is not a problem to & & 0.811 \\
fishing livelihood & 1.83 & 0.621 \\
Community is accessible despite poor road network & 1.33 & \\
Have access to credit facilities to support other livelihoods & &
\end{tabular}

${ }^{*}$ Agreed (mean $\left.\geq 2.50\right)$

\section{Livelihood Diversification Index of the Respondents}

Herfindel index was used to determine the extent of diversity in livelihood activities of the respondents. The index provided clear dispersion of activities in the area and ranges between 0 and 1 . The higher the degree of diversification, and vice versa. The computed Herfindel livelihood diversification index ( $\mathrm{LDIH}_{\mathrm{H}}$ ) was 0.43 (Table 4). This suggests a high level of diversification among the respondents. The proportion of total income from various livelihood categories was led by crop farming $(0.61$; mean A452,267.90) and distantly followed by non-farm $(0.21 ; A 159,034.50)$, fisheries $(0.10$;

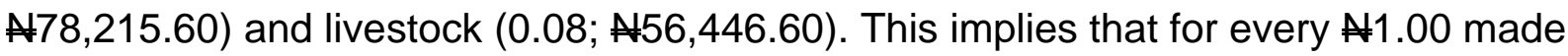
by fishers, non-fisheries livelihoods contribute $\mathrm{N} 0.90$. The result suggests that diversification has a positive effect on net income. 


\section{Table 4: Livelihood Diversification Index (LDIH)}

\begin{tabular}{lccc}
\hline Livelihood categories & Mean & $\begin{array}{c}\text { Proportion of } \\
\text { total income }\end{array}$ & $\begin{array}{c}\text { Squared } \\
\text { proportion }\end{array}$ \\
\hline Fisheries & $78,215.60$ & 0.10 & 0.011 \\
Crop production & $452,276.90$ & 0.61 & 0.368 \\
Livestock & $56,446.60$ & 0.08 & 0.006 \\
Non-farm activities & $159,034.50$ & 0.21 & 0.045 \\
Gross total & $745,973.60$ & 1.00 & \\
Livelihood diversification & & & 0.430 \\
index & & & \\
\hline
\end{tabular}

The Geometric Index $(\mathrm{Gl})=0.19$ (Table 5 ) revealed low vulnerability of each activity income on total income of fisher's livelihoods. The Geometric Index (GI) $=0.19$ shows that fishers already know that they are confronted with the challenges of sustainable fish catch resulting to low income and so they diversified more to other sources of income outside fishing.

\section{Table 5: Geometric Index (GI)}

\begin{tabular}{|c|c|}
\hline Livelihood categories & Mean Income (A) \\
\hline Fisheries & $78,215.60$ \\
\hline Crop production & $452,276.90$ \\
\hline Livestock & $56,446.60$ \\
\hline Non-Farm Activities & $159,034.50$ \\
\hline $\begin{array}{l}\text { Average mean } \\
\text { Geometric mean } \\
\text { Geometric Index }\end{array}$ & $\begin{array}{l}186,493.40 \\
133,492.46 \\
0.19\end{array}$ \\
\hline
\end{tabular}

\section{Sustainability Index of the Respondents}

The computed sustainability index (0.57) of the respondents implies that the livelihoods of the respondents are unsustainable. This is the direct outcome of insufficient earnings from fishers' current livelihoods. According to Venkatesh (2006), fishers are one of the most vulnerable groups of the world. He further stated 
that the nature of most fishers' livelihoods and their living conditions make them one of the poorest and most marginalized group. A critical underlying factor responsible for this is that the transforming structures and processes required for improving rural livelihoods toward achieving sustainability and reduced vulnerability is not in proper perspective.

\section{Conclusion and Recommendations}

Respondents had low livelihood assets. The sustainability index of the respondents indicated that the livelihoods of the respondents are unsustainable and vulnerable. There was a high level of diversification among the respondents.

i. Stakeholders in fishery should organize fishers into formal and functional groups to enable them harness financial capital targeted at fostering improvement in fishing household that will enhance the development of rural economy.

ii. Government at all levels should improve infrastructure in fishing communities for increase fishers' access to productive assets.

\section{References}

Apata, T.G., Akinlua, J.Y and Igbalajobi, O.A. (2009). Determinant of poverty and household livelihood diversification stratigies in crude oil producing areas of Ondo State, Nigeria.

Journal of Global Approaches to Extension Practice. Vol.5, No1. Pp. 122-134.

Apata T.G and Rahji M.A.Y (2012). Livelihood diversification strategies: Effects and a pathway out of poverty. Case study of farming households in crude-oil producing communities of Ondo state Nigeria.www.//http.ssm.com/abstract

Dercon, S. (2001). Assessing vulnerability to poverty: Paper prepared for

DFID.www.economics.ox.ac.uk/members/stefan.dercon

Department for Food and International Development of the United Kingdom (DFID) / Food and Agricultural Organisation (FAO) (2004). Sustainable

Fisheries Livelihood Programmes (SELP): A participatory rural appraisal of Tatabu fishing community, Niger State, Nigeria. NIFFR/GEP/INT/735/UK, Pp. 9, 17-18. 
Food and Agricultural Organisation (FAO) (2002). Food and Agriculture Organisation, Year Report 2002. FAO Rome. Pp. 1-6.

Food and Agricultural Organisation (FAO) (2004). DFID project on data collection and sharing mechanism for co-management identification of system requirements. Report in Preparation for the Guidelines Development Workshop. Level 4 International Management Advisory Bodies, Fisheries Department, FAO. 8pp

Food and Agricultural Organisation (FAO) (2006). Nigeria's fisheries profile. www.fao.org/fi/fcp/en/NGA. Retrieved on March 5, 2006.

Food and Agricultural Organisation (FAO) (2007). Fish Country Profile, FAO. The Federal Republic of Nigeria. FID/CP/NIF. 24pp.

Federal Department of Fisheries (FDF) (2008). Fisheries statistics of Nigeria. Federal Department of Fisheries, Abuja.

Federal Department of Fisheries (FDF) (2010). Fisheries statistics of Nigeria. Federal Department of Fisheries, Federal Ministry of Agriculture and Rural Development, Abuja.

Mutume, G (2002). Africa seeks to safeguard its fisheries. Africa Recovery, Vol 16 No $1, \quad$ p.12.

Nwabeze, G.O and Erie, A.P (2013). Artisanal Fishers' Use of Sustainable Fisheries Management Practices in the Jebba Lake Basin, Nigeria. Journal of Agricultural Extension Vol.17 (1), Pp 123-134

Ohen S.B, Agom, D.E and Okon U.H (2009). Economic of catfish farming in Rivers state. Proceedings of the $23^{r d}$ Annual National Conference of Farm Management Society of Nigeria, 14- $17^{\text {th }}$ December, Sokoto Nigeria. Pp570-572.

Olufemi, D.O (2008). Endoparasitic Helminths of the upside-down catfish, synodontis membranaceus (Geoffrey Saint Hilarie) in Jebba Lake, Nigeria. International Journal of Zoological Research. Vol 4 No.3. Pp 181-188.

Oyesola, O. B and Oladeji, J. O (2008). Social Capital and Income Generating Activities of Rural Women in Ondo State Nigeria. Nigerian Journal of Rural Sociology, Vol.8 No 2. p 49.

Qizilbashi, M (2001). A note on the measurement of poverty and vulnerability in the South Africa context. Paper presented for the development studies association conference, 2001, University of Machester, 10 -12 September, 2001. 
Creative commons User License: CC BY-NC-ND

Abstracted by: EBSCOhost, Electronic Journals Service (EJS),

Google Scholar, Directory of Open Access Journals (DOAJ),

Journal Seek, Scientific Commons,

Food and Agricultural Organization (FAO), andCABI
Journal of Agricultural Extension

Vol. 20 (1) June, 2016

ISSN(e): 24086851; ISSN(Print); 1119944X

http://journal.aesonnigeria.org

http://www.ajol.info/index.php/iae

Email: editorinchief@aesonnigeria.org

Venkatesh, S (2006). Trend in poverty and livelihoods in coastal fishing communities of OrissaState, India. FAO Fisheries Technical Paper 490, Rome, p 111. 